\title{
EQUINE ASSISTED LEARNING: SYMBOLIC VALUE OF HORSE AS UNDERLYING PATTERN IN HUMAN THINKING
}

\author{
Ilona Gehtmane-Hofmane \\ University of Latvia, Latvia
}

\begin{abstract}
Traditional pedagogy do not stressed the unique and challenging needs of the adult learner for a different kind of educational experience that was more engaging, more flexible and more appreciative of the existing knowledge base and experience of the adult learning. Equine Assisted Learning is a practice in which adults engage in systematic and sustained self-educating activities in order to gain new forms of knowledge, skills, attitudes, or values. The purpose of this research is to illustrate the meaning and symbolic value of horse as underlying pattern in human thinking.
\end{abstract}

Keywords: Equine Assisted Learning, horses.

\section{Introduction}

Traditional pedagogy do not stressed the unique and challenging needs of the adult learner for a different kind of educational experience that was more engaging, more flexible and more appreciative of the existing knowledge base and experience of the adult learning. Equine Assisted Learning for adults is an innovative, informal educational approach. Equine Assisted Learning courses and programmes is based on andragogy assumptions of Adult Learners and offers Androgogical process model of human learning and development in which facilitator establish a climate for learning, together with learner identified learning needs, formulate program objectives that will satisfy those needs, design a pattern of learning experiences, conduct these learning experiences with Equine Assisted Learning techniques and strategies for facilitating learning. Equine Assisted Learning is the process of engaging adult learners in the structure of the learning experience. As informal learning approach Equine Assised Learning is less organized and less structured than either formal or nonformal learning. It involves very little reliance on pre-determined guidelines for its organization, delivery and assessment, although it must be undertaken with the specific intention to develop some skills or knowledge. 
According to Manifesto for Adult learnig in the 21th Cenury (European Association for the education of adults) not only the direct learning outcomes are important for adults (European Association for the education of adults, n.d.).

Equine Assisted Learning is a practice in which adults engage in systematic and sustained self-educating activities in order to gain new forms of knowledge, skills, attitudes, or values.

The notion Equine Assisted Learning in literature is new and it appeared only at the beginning of the 20th century with the development of this field. Equine Assisted Learning practice was taking place in variety of settings. Currently, there are several hundred programs across the world that utilize Equine Assisted Interventions programmes for different learning needs for children, adolescents, and adults. Horses was taking place in prison programs, horses were involved in corporate development programs, domestic abuse programs, juvenile detention, in school settings. It seems there were no bounds to the creativity involved putting people and horses together for whatever reason. A range of practitioners from different backgrounds were involved in creating and delivering Equine Assisted Learning programmes. These learning programs function under the different theoretical framework and therefore do not deliver learning and training services using equivalent principles or techniques. Equine Assisted Learning have broad multidisciplinary content and is grounded in participants experience. The positive outcomes that can be obtained from learning activities with horses are primarily illustrated through the marketing literature, feedback from participants or practitioners, theoretical reasons why horses should be involved, and through small scale outcome based research. Equine Assisted Learning practice is based on empirical work and is not theoretically founded in research data.

\section{Findings}

The purpose of this research is to illustrate the meaning and symbolic value of horse as underlying pattern in human thinking. The one of the foremost anthropologists of our time Levi-Strauss (1983) suggested that mythemes are grounded in concerns that are universal for all humans across all cultures (LeviStrauss, 1983). By understanding how horses are portrayed in human thinking, we can to understand the human horse relationship which exist outside of any physical interaction with them.

Considering the varied ways in which humans perceive, engage, compete and co-exist, learn from and with non-human animals like horses is a range of cultural contexts (Davis \& Maurstad, 2016; Anthony, 2010; Johns, 2006). There has a massive outpouring of love for American-born Swiss singer Tina's Turner 
song "Simply The Best" written by Mike Chapman and Holly Knight. This is interesting for many reasons, not least because pop art is usually enjoyed. The symbol of the horse in her music video has captured something in the collective consciousness. Internationally - recognized authority on horse behavior Chris Irwin (2001) indicates some link between horses and human psyche and distinguishing feature of Jung concept of archetypes, symbols and collective unconsciousness. Irwin in his interview (2001) argues that most commonly recurring archetypes is the horse. He considers that the horse archetype has been closely linked with human instinctive, primal drives and evokes intense feelings. Irwin (2001) argues that in many different situations and in many different ways, horses were enabling humans to make contact with feelings they'd buried deep inside. Irwin wrote that horses is one of the deepest archetypes in human consciousness, and can be a direct connection into the unconscious (Irwin, 2001). Jung about collective unconscious postulated „The collective unconscious ... appears to consist of mythological motifs or primordial images, for which reason the myths of all nations are its real exponents. In fact, the whole of mythology could be taken as a sort of projection of the collective unconscious...” (Jung, 1960: p. 152). Archetypes are universal patterns that derive from the collective unconscious and are psychological and physiological construction that insufficient to represent all our projections onto horse.

Beverley (2004) wrote „Speed. Strenght. Grace. Power. Beauty. Every physical horse is a living myth unto its beholder...To see, smell, touch, fear, and mount a horse in the flesh is to feel the stirrings of archetypal energies araising from at least 35000 years of human awareness of horse” (Beverley, 2004). Midkiff (2002) says „A horse's body and limbs are not just palpable but symbolic, not just functional but suggestive” (Midkiff, 2002: p. 1).

In nowadays most humans become familiar with horse mainly through sport, movies, folk and fairy tales. For most them, only a mythical relationship to horse exists. In Latvian folklore horses were often anthropomorphized, for example, they spoke like humans. J. Stauga (Stauga, 2011) indicates that the horse is one of the most commonly encountered animals which is associated with earth fertility deities and yield in the middle region of the balts. The horse, as the personification of heavenly deities, has been relatively widely discussed in latvian folklore. J. Stauga (Stauga, 2011) points out that in latvian folklore all stages of human life are connected with horse. The horse's color also has been given a magical meaning (Stauga, 2011). The horse has been an important object of fortune telling and prophecy. Deities - Ūsiņš or Jurgís and Mārtiņš appear as horse-guardians in Latvian songs. For ancient latvians horse has been the symbol of the Sun Cult (Stauga, 2011). In many others mythological traditions, for example, Eqyptian, Greek, Armenian, Norse, Hindu horses also pull the sun. In world mythology and folklore there is approximetly 50 well known mystical 
horses, for example: Arion is a divinely-bred, swift immortal horse which was endowed with speech; Arvakr are the horse which pull the sun; Enbarr the horse, which could traverse both land and sea; Al Borak, a horse with the head of a woman and the wings of an eagle; Bucephalus, a horse mythically enhanced from historical record; Pegasus, a flying horse usually depicted as white coloured; Centaurs, a hybrid race of horse and human, are known for their barbarism. Horses have also been the bearers of essence such as Celtic horse goddess Epona, an archetype of fertility and transformation (Llywel, 1982).

Horse is the one of 12 zodiak symbols. Many myths and images portray horse as the vehicle for mythical journeys and magical powers. Horse is the object of rituals, consecration and meditation. Most folklore tales portray horse as extending the physical abilities of his rider and so becoming an accessory as a symbol of greatness.

Horse appears in forms that correspond to Jungian archetypes Anima and Animus. Animus and Anima are the two primary anthropomorphic archetypes of the unconscious mind, the archetypal figures that hold masculine and feminine qualities. Jung believed that while the Anima tended to appear as a relatively singular female personality, the Animus may consist of a conjunction of multiple male personalities (Jung, 1951). Kohanov (2001) international attention received author and founder of Epona Equestrian Services, lecturer and horse trainer claims that the horse relate to the world from primarily feminine qualities. In her book „The Tao of Equus” (2001) she wrote „As a result, the species is a living example of the success and effectiveness of feminine values, including cooperation over competition, responsiveness over strategy, emotion and intuition over logic, process over goal, and the creative approach to life that these qualities engender” (Kohanov, 2001, xxiii). In her other book „Way of the Horse: Equine Archetypes for Self-Discovery" (2007) Kohanov offer 4 types of equine archetypes that humans absorbe through working with horses: 1 . Archetypes of Experience: What horse teach us about balance, timing, agility, power, and collection; 2. Archetypes of Relationship: What horse reveal about leadership, dominance, boundaries, and community; 3. Archetypes of Creativity: How horses inspire authenticity, imagination, and innovation; 4. Archetypes of Transformation (Kohanov, 2007, p. 10.).

As shown by the author's survey in the period from 2014 to 2017, in which 200 respondents participated, humans project onto horse sensations of size, strenght, grace, coordination, agility, speed, danger, freedom, love, life, wisdom, agility, trust, stability, warmth, dream, cooperation, romance. One of the more remarkable aspects of a horse in respondents' answers that he expresses both strong masculine and strong feminine qualities, as well as behavioral aspects 
that seem to be is paired opposites, for example: big, strong yet fearful, hardy yet sensitive, easily domesticated and trainedand yet wild and unpredictable.

Horse has ability to inspire humans through archetypes and symbols, dreams and fantasies, reaching out to the conscious and unconscious mind. Horse is a purposeful non-verbal intervener, consciously using physical expression through body, gestures, emotional intent. For contemporary cultures no longer dependents from the horse for food, battles or transportation. Horse has ceased to be part of human daily life. However the horse, with its inherent grace, intelligence and courage, has inspired the strongest feelings of empathy an affinity reflected in more than 30,000 years of artistic representation (Pickerl T., 2009), horses have always been an important part of the movie industry, horses still have in literature and in religious writings, in legends, in Tarot cards, in mythologies (Hausman G., \& Hausman L., 2012), in folklores and in fairytales, in sport, in parades and police patrols or as an partner, mediator, agent of learning content in Equine Assisted Learning practice. The role of horses in shaping world civilizations and changing lives has been recognized for a long time (Forreest, 2016), hovewer, majority educators and many other professionals still find it difficult to understand the special characteristics of the horse in Equine Assisted Learning practice and how it is capable for human learning and development. The emergence of the beneficial effects of the interaction with the horse for learning purposes needed to be intended.

\section{Conclusion}

Equine Assisted Learning for adults is an innovative, informal educational approach. Equine Assisted Learning courses and programmes is based on andragogy assumptions of Adult Learners. Equine Assisted Learning is the process of engaging adult learners in the structure of the learning experience. The purpose of this research is to illustrate the meaning and symbolic value of horse as underlying pattern in human thinking. By understanding how horses are portrayed in human thinking, we can to understand the human horse relationship which exist outside of any physical interaction with them. The symbol of the horse has captured something in the collective consciousness. In nowadays most humans become familiar with horse mainly through sport, movies, folk and fairy tales. For most them, only a mythical relationship to horse exists. Horse appears in forms that correspond to Jungian archetypes Anima and Animus. As shown by the author's survey in the period from 2014 to 2017, in which 200 respondents participated, humans project onto horse sensations of both strong masculine and strong feminine qualities, as well as behavioral aspects that seem to be is paired opposites. Horse has ability to inspire humans 
Gehtmane-Hofmane, 2018. Equine Assisted Learning: Symbolic Value of Horse as Underlying Pattern in Human Thinking

through archetypes and symbols, dreams and fantasies, reaching out to the conscious and unconscious mind. Horse is a purposeful non-verbal intervener, consciously using physical expression through body, gestures, emotional intent. Hovewer, majority educators and many other professionals still find it difficult to understand the special characteristics of the horse in Equine Assisted Learning practice and how it is capable for human learning and development. The emergence of the beneficial effects of the interaction with the horse for learning purposes needed to be intended.

\section{Referneces}

Anthony, D. W. (2010). The Horse, the Wheel, and Language: How Bronze-Age Riders from the Eurasian Steppes Shaped the Modern World. Princeton University Press.

Beverley, K. (2004). Day mares and night stallions: archetypes in the mythology of horses. Part 1. Myth, archetype, and somarchetype. Retrived from: http://www.horsensei.com/ publications/MythologyofHorses/index.html

Davis, D. L., \& Maurstad, A. (2016). The Meaning of Horses: Biosocial Encounters. Routledge.

European Association for the education of adults (n.d.). Retrived from: http://www.eaea.org/ en/policy-advocacy/manifesto-for-adult-learning-in-the-21st-century.html

Forrest, S. (2016). The Age of the Horse: An Equine Journey through Human History. Retrived from: https://books.google.lv/

Irwin, C. (2001). Horses Help with Human Psychotherapy. Equisearch. Retrived from: http://www.equisearch.com/resources/eqirwin813

Hausman, G., \& Hausman, L. (2012). The Mythology of Horses: Horse Legend and Lore Throughout the Ages. Retrived from: https://books.google.lv/

Hintz, H. F. (1979). Horses in the movies. Published by A. S. Barnes, U.S.A.

Jung, C. G. (1951). Aion: The Phenomenology of the Self, published in Volume 9, part 2, of the Collected Works. Retrived from:

https://archive.org/stream/collectedworksof92cgju/collectedworksof92cgju_djvu.txt

Johns, C. (2006). Horses: History, Myth, Art. The British Museum Press

Jung, C. G. (1960). The Structure of the Psyche. Collected Works 8, Paragraph 325, p. 152. Retrived from: https://books.google.lv/

Kohanov, L. (2001). The Tao of Equus: A Woman's Journey of Healing and Transformation through the Way of the Horse. Retrived from: https://books.google.lv/

Kohanov, L. (2007). Way of the horse: Equine Archetypes for Self-Discovery. New World Library, California.

Levi-Strauss, C. (1983). Structural Anthropology. Volume 2. Retrived from: https://books.google.lv/

Llywelin, M. (1982). The Horse Goodness. A Tom Donkerty Associates Book, New York.

Midkiff, M. D. (2002). She Flies Without Wings: How Horses Touch a Woman's Soul. Dell Publishing Random House. Inc.

Pickerl, T. (2009). The Horse: 30,000 Years of the Horse in Art. Merrell Publishers Limited.

Stauga, J. (2011). Dzīvnieki latviešu folklorā: mītiski maǵiskais aspekts. Promocijas darbs filolog̣ijas doktora grāda iegūšanai folkloristikas zinātnes nozarē. Latvijas Universitāte 